\section{Esthetic Crown Lengthening Involving Dental Implants and Natural Teeth: A Case Study}

\section{Abstract}

Objective: This paper presents a rare management of excessive gingival display around dental implants and natural teeth using a minimally invasive approach to reduce peri-implant soft tissue with limited osseous reduction around natural teeth. It highlights esthetic crown lengthening procedure creating symmetrical gingival margins in the maxillary anterior region around dental implants and natural teeth.

Clinical considerations: Excessive gingival display or gummy smile may adversely impact patient's appearance leading to esthetic concerns. Careful management of soft tissues around dental implants differs than that around teeth to achieve esthetic results. A technique is presented to esthetically and biologically align the gingival margins in areas of implants and natural teeth. It combines soft tissue reduction for implants with limited osseous and soft tissue reduction around natural teeth to achieve symmetrical results.

Conclusion: Based on objectively evaluating the results using PES and WES parameters, esthetic results can be achieved around natural teeth and implants with excessive gingival display, through establishing a natural harmonious smile with stable outcomes at 24 months follow up.

Keywords: Crown lengthening; Dental implants; Esthetic

\section{Bassam M Kinaia, Kiran Agarwal and Maanas Shah}

\author{
Graduate Periodontics Program, University \\ of Detroit Mercy School of Dentistry, \\ 2700 Martin Luther King Jr. Blvd, Detroit, \\ Michigan 48208, USA
}

Corresponding author: Bassam M. Kinaia

\section{”kinaiaperio@gmail.com}

Director, Graduate Periodontics Program, University of Detroit Mercy School of Dentistry, 2700 Martin Luther King Jr. Blvd, Detroit, Michigan 48208, USA.

Tel: +12489537676

Citation: Kinaia BM, Agarwal K, Shah M. Esthetic Crown Lengthening Involving Dental Implants and Natural Teeth: A Case Study. Periodon Prosthodon. 2016, 2:2.

Received: July 22, 2016; Accepted: July 27, 2016; Published: July 29, 2016

\section{Introduction}

Excessive gingival display or gummy smile with altered position of the dento-gingival complex gives the appearance of short clinical crowns or undesirable gingival symmetry leading to unaesthetic smile [1]. This bears an emotional and psychological impact on patients [2-4]. Esthetic crown lengthening (ECL) aims to reduce excessive soft and hard tissues to establish a natural smile with harmonious proportion between the teeth and the dentogingival complex. It combines a healthy dentogingival complex and restorative treatment with good marginal seal, retention and function to maximize the long-term success of the definitive restoration [5]. The etiologies of excessive gingival display or gummy smile are vertical maxillary excess, gingival enlargement, short or hypermobile upper lip or altered passive eruption [6,7]. Various classifications exist to help in the diagnosis and treatment planning for ECL [7-9]. Coslet classified altered passive eruption into four categories based on the relationship of the osseous crest and mucogingival junction to the CEJ. The need for osseous or soft tissue reduction is determined by the position of the osseous crest in relation to the CEJ and the amount of remaining keratinized gingiva (KG) present. Consideration must also be made to determine adequate distance for the biologic width that is an important factor in the maintenance of periodontal health during restorative therapy $[10,11]$. Violation of the biologic width will result in chronic irritation of periodontal tissues leading to inflammation and bone loss with unpleasant esthetics [10-12].

The aforementioned classifications and treatment options are primarily used around natural teeth with the goal of providing esthetic and healthy dentogingival complex without violation of the biologic width. Nonetheless in today's dental practice, the number of dental implants placed is on the rise approaching 3 million in the United States with an increase of 500,000 implants annually [13]. Excessive gingival display around dental implants is uncommon, and rather implants often have thin soft tissue or gingival recession [14-16]. Thus, ECL in areas involving dental implants and natural teeth can present a challenge. There is very little information in the literature regarding resective therapy around dental implants [17]. The current case report presents careful management of excessive gingival display around dental implants and natural teeth in the esthetic zone to establish a harmonious natural smile. 


\section{Case Presentation}

A healthy 54 year-old female patient presented to the Periodontic Department clinic with excessive gingival display and asymmetrical gingival margins in the maxillary anterior region (Figure 1). The patient was referred from the Prosthodontic Department with proposed treatment plan for full mouth rehabilitation. The clinical examination revealed presence of full maxillary arch provisional restorations with healthy gingival tissues. The smile analysis showed disproportional maxillary clinical crown lengths with high gingival margins position for upper right and left canine and upper central and lateral incisors (Figure 2). Hence, the clinical crowns appeared shorter on the right compared to the left maxillary anteriors. Radiographically, osseointegrated implants (Tapered Screw-Vent ${ }^{\circledR}$, Zimmer Dental Inc., Carlsbad, CA, USA) and natural teeth were present in the maxillary anterior region. Clinically, adequate amount of keratinized gingiva was present with probing depths of 2-3 $\mathrm{mm}$. Projected restorative treatment required an increase in clinical crown length for the upper central incisors and symmetrical crown lengths for the lateral incisors and canines. Upon bone sounding, the osseous crest in the anterior maxillary region was in close proximity to the anticipated margins of the future final restorations. ECL was recommended with the goal of creating an esthetically pleasing smile through balanced gingival contour and symmetrical clinical crowns without violation of the biologic width.

The patient rinsed with a $0.12 \%$ chlorhexidine (Hi-Tech Pharmacal Co., Inc. Amityville, NY, USA) solution for a minute presurgically. Local anesthesia was administered using $2 \%$ lidocaine with 1:100,000 epinephrine (Empi, Inc., St. Paul, MN, USA). Preoperative crowns lengths were measured outlining the amount of soft tissue reduction required to determine proposed clinical crowns lengths (Figure 3). Biologic width measurements were determined by bone sounding. Internal bevel gingivectomy of 1.0 to $1.5 \mathrm{~mm}$ was performed for maxillary right canine, lateral and central incisors and left central incisors to achieve symmetrical clinical crown lengths (Figure 4). A full thickness facial flap was reflected while maintaining the integrity of the palatal tissues (Figure 5). No flap was reflected for the upper left dental implants since clinical crown lengths and gingival margins were esthetically acceptable. Osteoctomy and osteoplasty was performed on the upper right teeth (Figure 6) while implant received minimal osteoplasty to establish periodontal sluiceway (Figure 7). Crestal

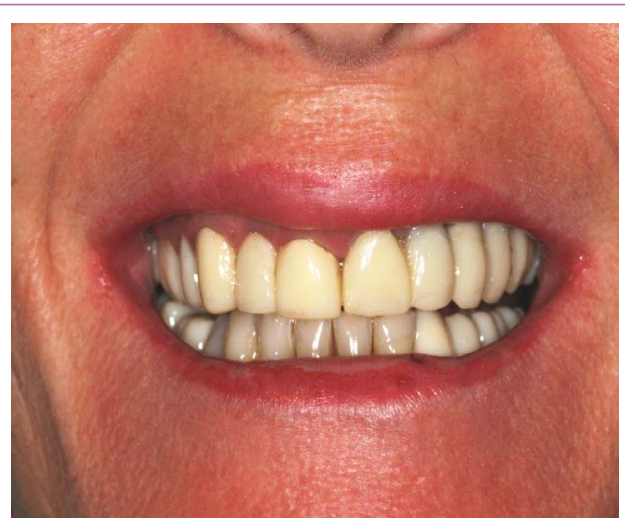

Figure 1 Facial view showing asymmetrical gingival margins with excessive gingival display on the right side.

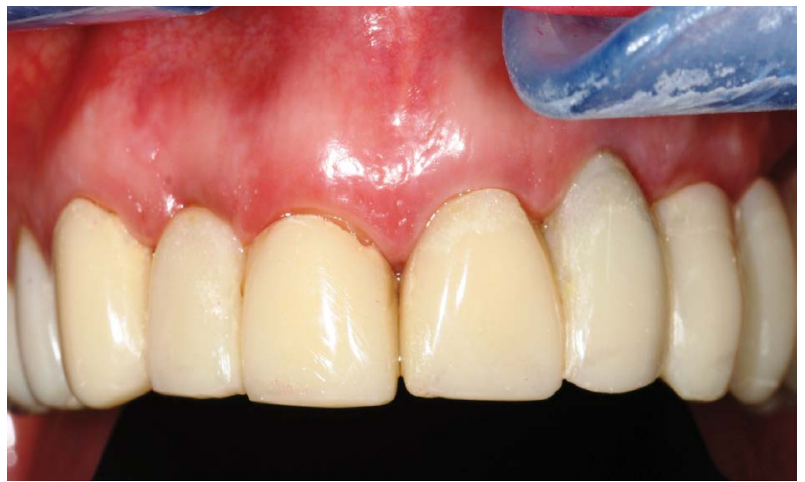

Figure 2 Facial view demonstrating full maxillary arch provisional restorations.
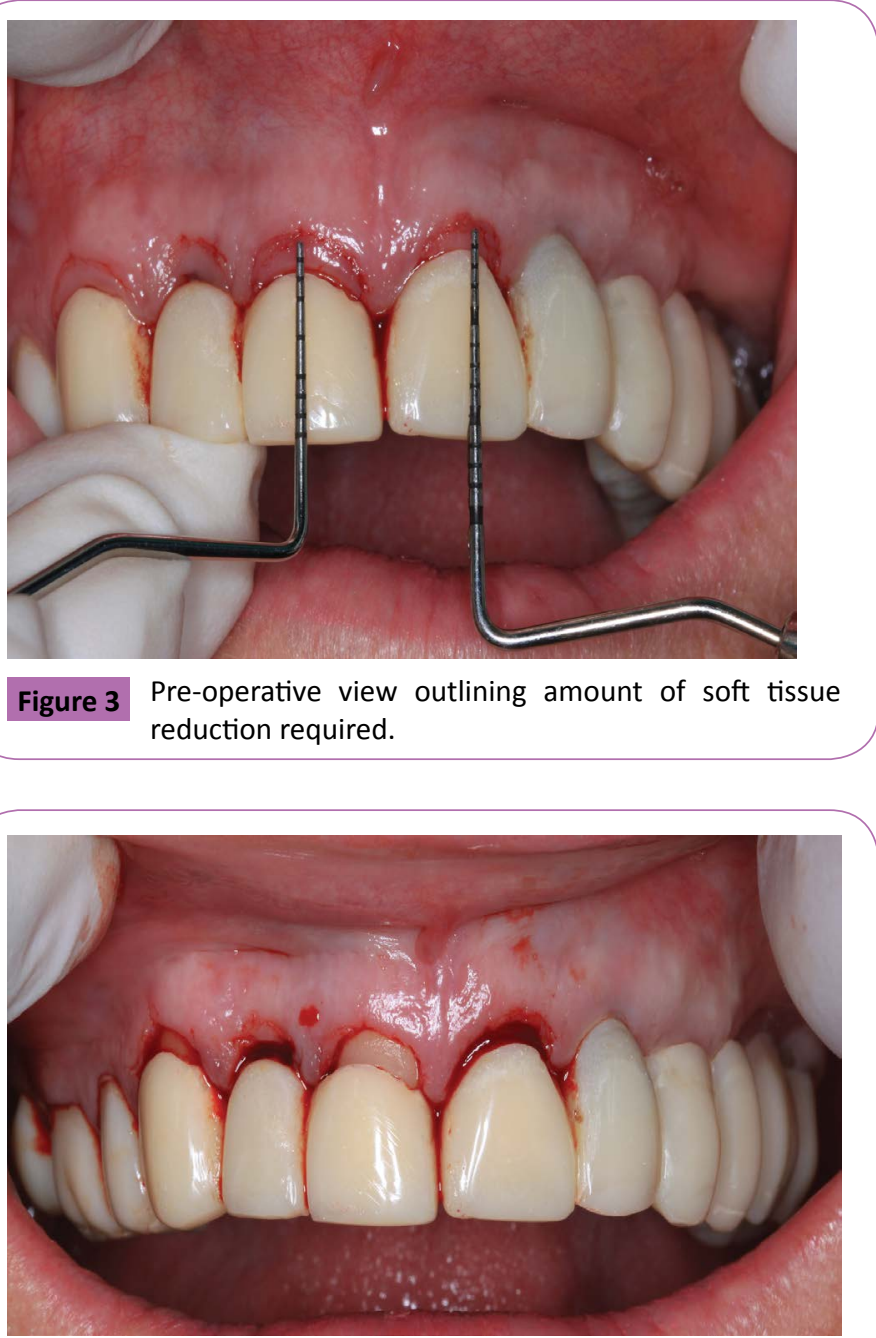

Figure 4 Facial view demonstrating gingivectomy for upper centrals and right lateral incisor and canine.

bone was recontoured and approximately $3.0 \mathrm{~mm}$ of biologic width was reestablished (Figure 8). The exposed natural teeth were thoroughly root planed to minimize the possibility of reattachment of residual connective tissue fibers [18]. No instrumentation was performed for the upper right dental implant (lateral incisor) to prevent scratches or gouges on the implant-abutment interface (Figure 9). It has been well documented that the interproximal 


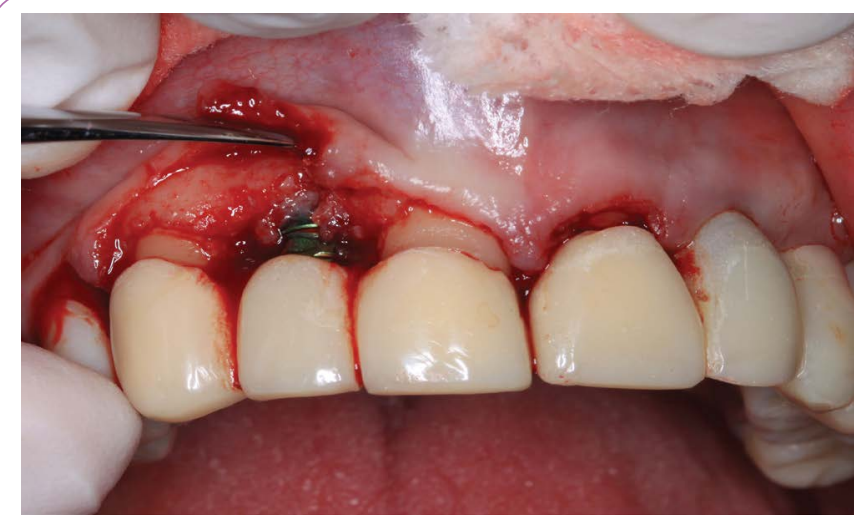

Figure 5 Facial view showing full thickness buccal flap reflection.

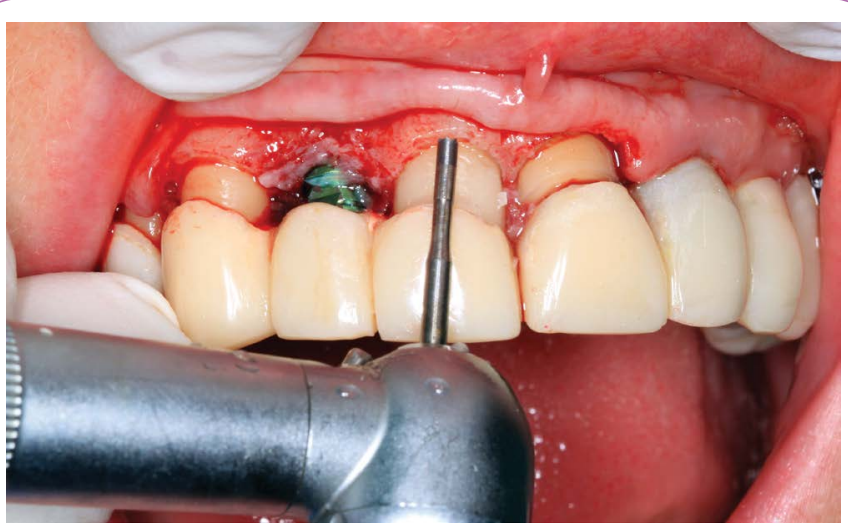

Figure 6 Facial showing ostectomy for natural teeth.

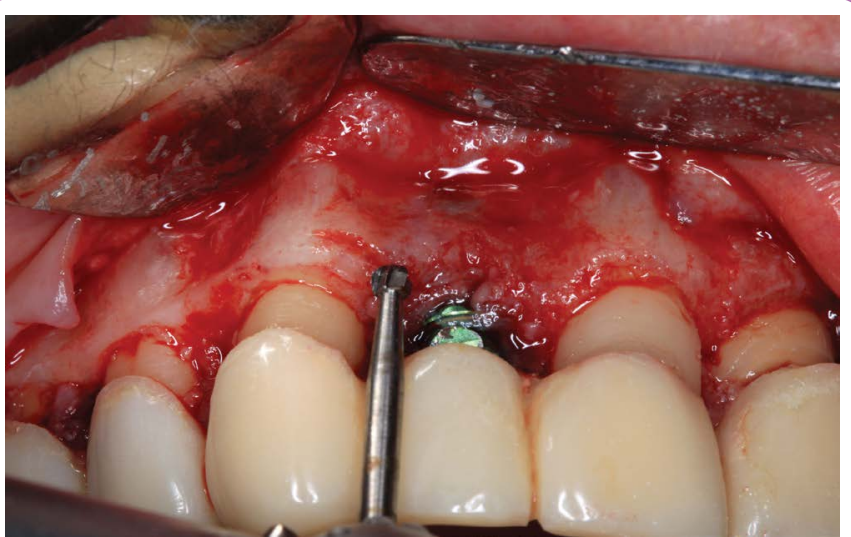

Figure 7 Facial showing osteoplasty for implant.

papilla will form if the distance from the contact area to the crest of the interdental bone is $5 \mathrm{~mm}$ or less [19]. According to Salama et al. the distance between the contact point and crest of alveolar bone in case of implant-tooth papillae of less than $4.5 \mathrm{~mm}$ will result in $100 \%$ papillae appearance [20]. Therefore, interproximal bone was re-contoured cautiously to minimize the chances of loss of papilla. Since the length of the papilla is approximately $40 \%$ to $50 \%$ of crown length, [21] the papilla was shortened 0.4 to $0.5 \mathrm{~mm}$ for every 1.0 $\mathrm{mm}$ that is disproportionate to the length of the clinical crown to maintain the appropriate crown-papilla ratio. The flaps were repositioned at the new gingival margin position maintaining bilateral symmetry of clinical crowns. Internal vertical mattress 5-0 resorbable sutures (Vicryl, Medline Industries, Inc. One Medline Place Mundelein, IL, USA) were used (Figure 10).

New provisional restorations were delivered at 5 weeks postsurgery using temporary cement (Temp-Bond. 3M ESPE AG, Seefeld, DE, USA) (Figure 11), and periodontal tissues were allowed to heal for an additional 8 weeks (Figure 12). After 6 months, implant impression copings connected to the implants (Figure 13) and final impression was taken using a polyvinylsiloxane material (Imprint II, 3M ESPE AG, Seefeld, DE, USA) (Figure 14). Definitive custom abutments were fabricated and connected to the implants at $30 \mathrm{Ncm}$ torque (Figure 15). The definitive crowns were manufactured and delivered approximately 8 months post surgery using all-Zirconia ceramic material (Procera, Nobel Biocare, Yorba Linda, CA, USA) with resin cement (Variolink, Ivoclar Vivadent, FL, USA) (Figure 16).

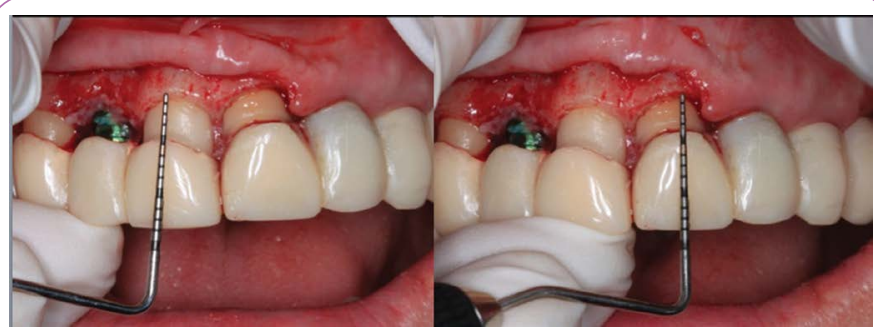

Figure 8 Facial view demonstrating adequate distance from bone crest to crown margin for establishment of biologic width.

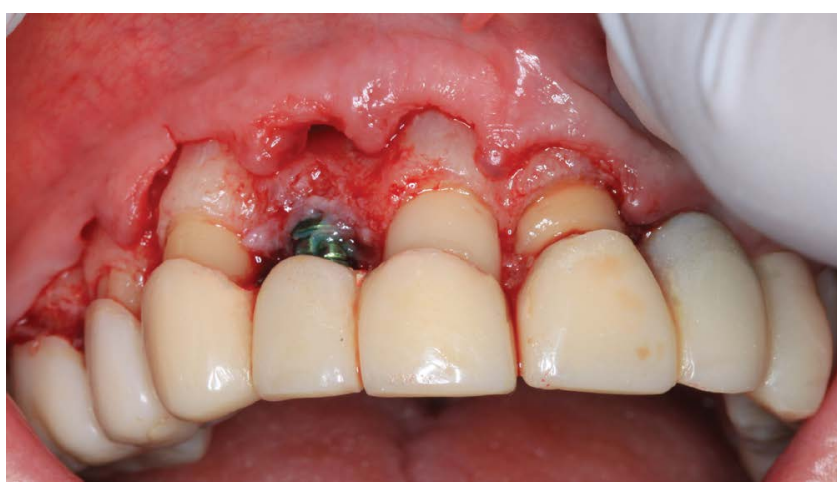

Figure 9 Facial view post osseous reduction for teeth and implant.

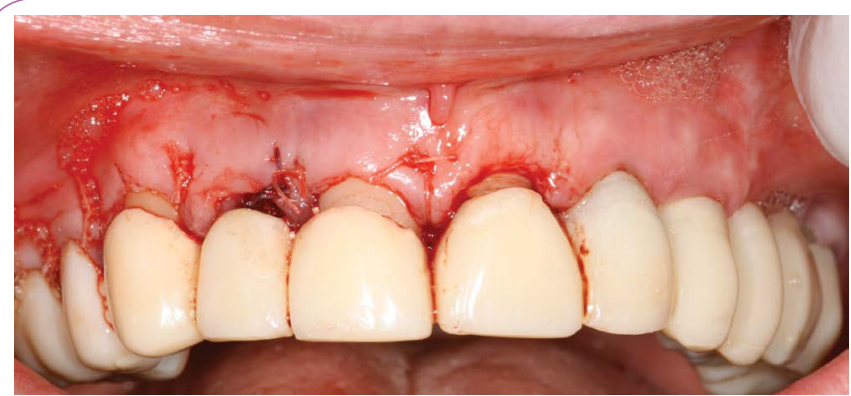

Figure 10 Facial view demonstrating flap closure maintaining papillary height. 


\section{Results}

Symmetrical gingival margins with esthetically pleasing clinical crown width to length ratios were achieved for the dental

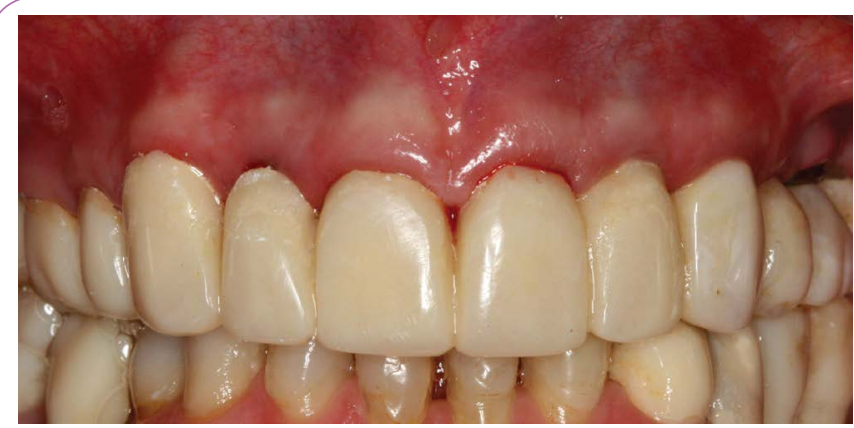

Figure 11 New provisional restorations delivered 5 weeks post surgery.

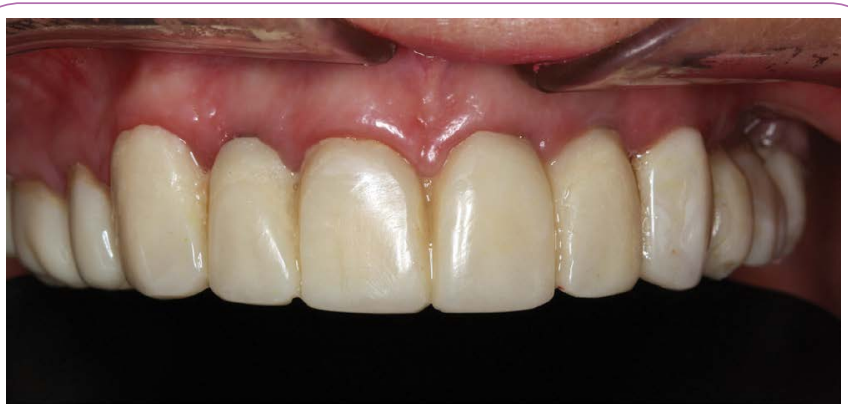

Figure 12 Facial view showing healing 8 weeks post surgically.

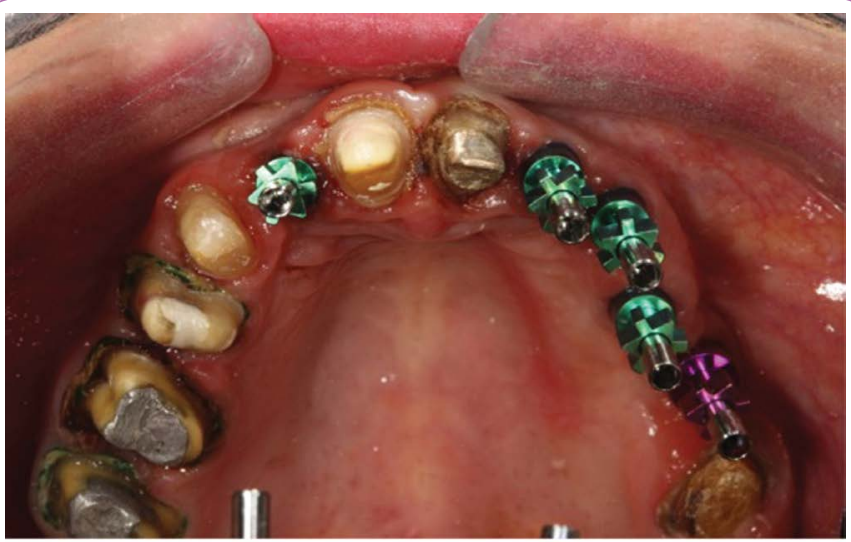

Figure 13 Occlusal view showing implant impression copings connected to the implants 6 months post surgery.

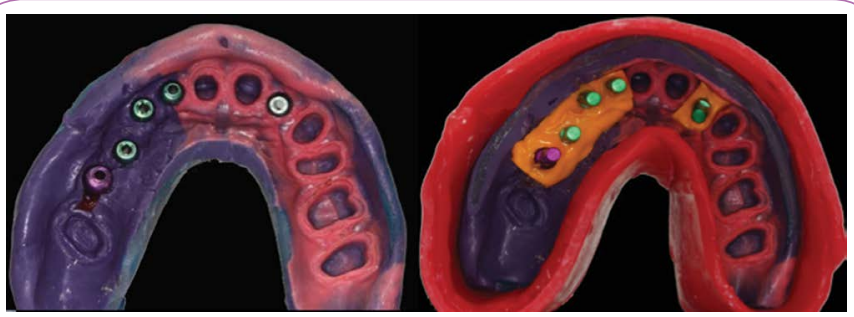

Figure 14 Final impressions with implant analogs.

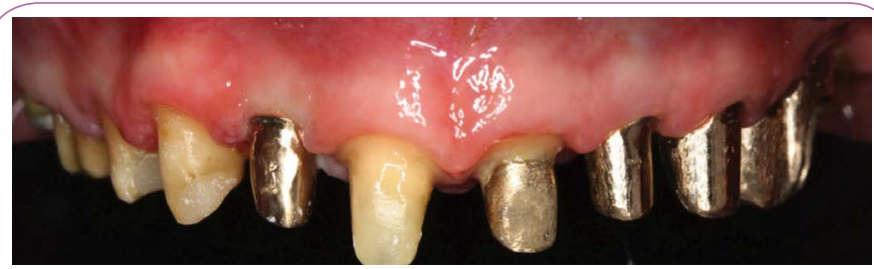

Figure 15 Facial view showing definitive custom abutments connected to the implants.

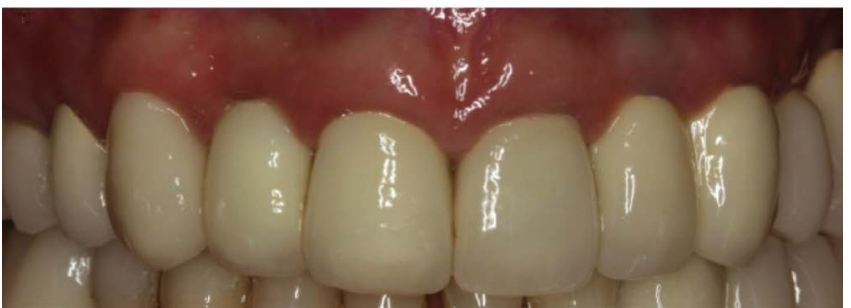

Figure 16 Facial view displaying final restorations placement.

implants and natural teeth. White esthetic score (WES) and pink esthetic score (PES) gives an objective assessment of the esthetic dimensions of the teeth evaluating different criteria such as the mesial/distal papilla, soft tissue texture and color etc [22]. The WES and PES scores calculated at the 24 months follow up showed improved values compared to the pre-operative scores (Table 1). The mean scores at 24 months follow up were $7.5+0.71$ and for PES 7.5+3.54 for WES (Table 2). Clinically, the soft tissues appeared to be stable around the definitive crowns at 12 (Figure 17) and 24 months follow-ups (Figure 18). The pre and post radiographic appearance showed stable and well osseointegrated implants (Figure 19).

\section{Discussion}

The majority of cases describing $\mathrm{ECL}$ in the literature involve natural teeth only. This case report deals with the management of the gingival tissues in an area involving natural teeth and osseointegrated dental implants to create esthetically pleasing gingival margins. Many anatomical and biological factors influence the soft and hard tissue responses around natural teeth and implants to obtain adequate esthetically pleasing results. Management of such clinical scenario requires special considerations due to inherent differences between the gingiva of natural teeth and the peri-implant tissues.

Anatomically, the clinical crown height is more than its width for the maxillary anterior teeth. The height is directly related to the position of the gingival margin and incisal edge. Initial investigation by Sterrett et al. analyzed clinical crowns widths, lengths and width to length ratios revealing a correlation among them [23]. They found width dimensions of $8.6 \mathrm{~mm}, 6.6 \mathrm{~mm}$ and $7.6 \mathrm{~mm}$ and lengths of $10.2 \mathrm{~mm}, 8.9 \mathrm{~mm}$ and $10.1 \mathrm{~mm}$ for the central, lateral incisors and canines respectively. The width to length ratios of $0.85,0.76$ and 0.77 with an average of $81 \%$ was suggested as esthetically pleasing dimensions [23]. These measurements are similar to Chu et al. recommendations of a $78 \%$ width to length ratios for esthetically pleasing smile [24]. To establish proper ratios, gingivectomy with or without osseous reduction are generally required during $E C L$ procedure. In the 
Table 1 Summary results of the preoperative and 24-months follow up for the Pink Esthetic Scores (PES) and White Esthetic Scores (WES). The 24 months follow up results demonstrate improvement in PES and WES scores compared to the preoperative scores for the maxillary anterior teeth. Pre-op PES and WES evaluation; 24 months PES and WES follow-up.

\begin{tabular}{|c|c|c|c|c|c|c|c|c|c|c|c|c|c|}
\hline \multicolumn{14}{|c|}{ Pre-op PES and WES evaluation } \\
\hline Site & $\begin{array}{l}\text { Mesial } \\
\text { Papilla }\end{array}$ & $\begin{array}{l}\text { Distal } \\
\text { Papilla }\end{array}$ & $\begin{array}{l}\text { Curvature of } \\
\text { facial mucosa }\end{array}$ & $\begin{array}{l}\text { Level of } \\
\text { Facial } \\
\text { Mucosa }\end{array}$ & $\begin{array}{l}\text { Root convexity, } \\
\text { Soft tissue color } \\
\text { and Texture }\end{array}$ & $\begin{array}{l}\text { TOTAL } \\
\text { PES }\end{array}$ & $\begin{array}{l}\text { Tooth } \\
\text { form }\end{array}$ & $\begin{array}{c}\text { Tooth } \\
\text { volume/ } \\
\text { Outline }\end{array}$ & $\begin{array}{l}\text { Color } \\
\text { (Hue/ } \\
\text { Value) }\end{array}$ & $\begin{array}{l}\text { Surface } \\
\text { Texture }\end{array}$ & $\begin{array}{c}\text { Translucency } \\
\text { and } \\
\text { Characterization }\end{array}$ & $\begin{array}{l}\text { TOTAL } \\
\text { WES }\end{array}$ & $\begin{array}{l}\text { TOTAL } \\
\text { PES+WES }\end{array}$ \\
\hline 6 & 2 & 1 & 2 & 1 & 2 & 8 & 1 & 1 & 1 & 1 & 0 & 4 & 12 \\
\hline $7-1$ & 2 & 1 & 1 & 0 & 1 & 5 & 1 & 1 & 1 & 0 & 0 & 3 & 8 \\
\hline 8 & 1 & 2 & 1 & 0 & 2 & 6 & 0 & 1 & 1 & 1 & 0 & 3 & 9 \\
\hline 9 & 1 & 1 & 1 & 1 & 2 & 6 & 1 & 1 & 1 & 1 & 0 & 4 & 10 \\
\hline $10-I$ & 1 & 1 & 1 & 0 & 2 & 5 & 1 & 1 & 1 & 0 & 0 & 3 & 8 \\
\hline $11-I$ & 1 & 1 & 2 & 1 & 2 & 7 & 1 & 1 & 1 & 1 & 0 & 4 & 11 \\
\hline Mean & 1.33 & 1.17 & 1.33 & 0.5 & 1.83 & 6.17 & 0.83 & 1 & 1 & 0.5 & 0 & 3.5 & 9.67 \\
\hline \multicolumn{14}{|c|}{24 months PES and WES follow-up. } \\
\hline Site & $\begin{array}{l}\text { Mesial } \\
\text { Papilla }\end{array}$ & $\begin{array}{l}\text { Distal } \\
\text { Papilla }\end{array}$ & $\begin{array}{l}\text { Curvature of } \\
\text { facial mucosa }\end{array}$ & $\begin{array}{l}\text { Level of } \\
\text { Facial } \\
\text { Mucosa }\end{array}$ & $\begin{array}{l}\text { Root convexity, } \\
\text { Soft tissue } \\
\text { color and } \\
\text { Texture }\end{array}$ & $\begin{array}{l}\text { TOTAL } \\
\text { PES }\end{array}$ & $\begin{array}{l}\text { Tooth } \\
\text { form }\end{array}$ & $\begin{array}{l}\text { Tooth } \\
\text { volume/ } \\
\text { Outline }\end{array}$ & $\begin{array}{l}\text { Color } \\
\text { (Hue/ } \\
\text { Value) }\end{array}$ & $\begin{array}{l}\text { Surface } \\
\text { Texture }\end{array}$ & $\begin{array}{c}\text { Translucency } \\
\text { and } \\
\text { Characterization }\end{array}$ & $\begin{array}{l}\text { TOTAL } \\
\text { WES }\end{array}$ & $\begin{array}{l}\text { TOTAL } \\
\text { PES+WES }\end{array}$ \\
\hline 6 & 2 & 2 & 2 & 2 & 2 & 10 & 2 & 1 & 2 & 2 & 0 & 7 & 17 \\
\hline $7-1$ & 2 & 2 & 2 & 1 & 1 & 8 & 2 & 1 & 2 & 2 & 0 & 7 & 15 \\
\hline 8 & 2 & 2 & 2 & 1 & 2 & 9 & 2 & 2 & 2 & 2 & 0 & 8 & 17 \\
\hline 9 & 2 & 2 & 2 & 1 & 2 & 9 & 2 & 2 & 2 & 2 & 0 & 8 & 17 \\
\hline I0-I & 2 & 1 & 2 & 1 & 2 & 8 & 2 & 1 & 2 & 2 & 0 & 7 & 15 \\
\hline 11-I & 1 & 1 & 2 & 2 & 2 & 8 & 2 & 2 & 2 & 2 & 0 & 8 & 16 \\
\hline Mean & 1.83 & 1.67 & 2 & 1.33 & 1.83 & 8.67 & 2 & 1.5 & 2 & 2 & 0 & 7.5 & 16.17 \\
\hline
\end{tabular}

Table 2 Summary results of the Mean Pink Esthetic Scores (PES) and White Esthetic Scores (WES) at 24 months follow up.

\begin{tabular}{|c|c|c|c|c|c|c|}
\hline \multicolumn{7}{|c|}{ PES } \\
\hline & Mesial Papilla & $\begin{array}{l}\text { Distal } \\
\text { Papilla }\end{array}$ & Curvature of facial mucosa & Level of Facial Mucosa & $\begin{array}{l}\text { Root convexity, Soft tissue } \\
\text { color and Texture }\end{array}$ & Total Score \\
\hline Maximum & 2 & 2 & 2 & 2 & 2 & 10 \\
\hline Minimum & 1 & 1 & 1 & 1 & 1 & 5 \\
\hline MEAN & 1.5 & 1.5 & 1.5 & 1.5 & 1.5 & 7.5 \\
\hline SD & 0.71 & 0.71 & 0.71 & 0.71 & 0.71 & 3.54 \\
\hline \multicolumn{7}{|c|}{ WES } \\
\hline & Tooth Form & Tooth Volume Outline & Color (Hue/Value) & Surface Texture & $\begin{array}{l}\text { Translucency and } \\
\text { Characterization }\end{array}$ & Total Score \\
\hline Maximum & 2 & 2 & 2 & 2 & 0 & 8 \\
\hline Minimum & 2 & 1 & 2 & 2 & 0 & 7 \\
\hline MEAN & 2 & 1.5 & 2 & 2 & 0 & 7.5 \\
\hline SD & 0 & 0.71 & 0 & 0 & 0 & 0.71 \\
\hline
\end{tabular}

current case, the position of the gingival margin was determined according to the clinical crown length and the smile analysis. The amount of keratinized gingiva present dictates the incision line [25]. The patient had adequate keratinized tissue present and gingivectomy was performed to establish symmetrical clinical crown ratios. Further, the management of the interdental papilla is another important anatomical factor during ECL. The interproximal papilla will completely fill in the interdental space when the distance from the bone crest to the base of interproximal contact area is $5 \mathrm{~mm}$ or less [19]. Thus, osteoctomy was performed on the facials of natural teeth and carefully blended in interproximally to minimize the chances of papilla loss. Any minor residual interproximal spaces can be adequately managed prosthetically by altering the positions of the contact area.
Biologically, the soft tissue seal around teeth develops during tooth eruption whereas the peri-implant mucosa forms after the creation of a wound in oral soft and hard tissues. Biologic width dimensions vary around natural teeth compared to dental implants. Gargiulo in his cadaver study described the biologic width to be $2.04 \mathrm{~mm}(0.97 \mathrm{~mm}$ epithelial attachment and $1.07 \mathrm{~mm}$ connective attachment) with an average sulcus depth of $0.69 \mathrm{~mm}$ [26]. In an animal study, Berglundh et al. examined anatomical and histological features of the peri-implant mucosa and compared them to those of around teeth. The mean biological width was $3.80 \mathrm{~mm}$ around implants versus $3.17 \mathrm{~mm}$ around teeth [27]. While there was no statistically significant difference in the height of the junctional epithelium and sulcus depth between implants and teeth, the height of the connective tissue attachment was 


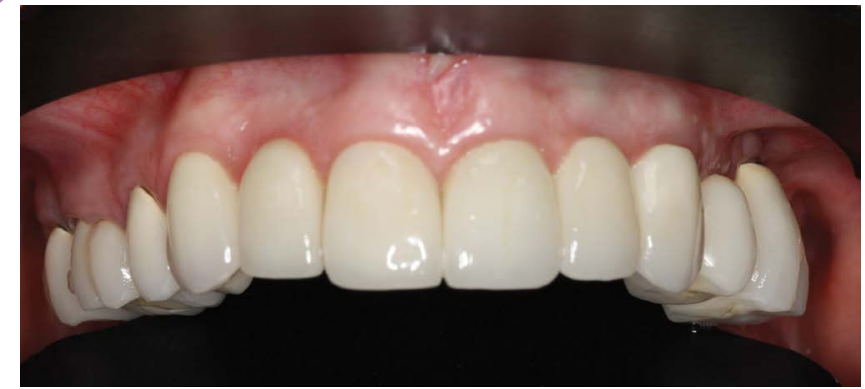

Figure 17 Facial view showing stable esthetic results at 12 months follow-up.

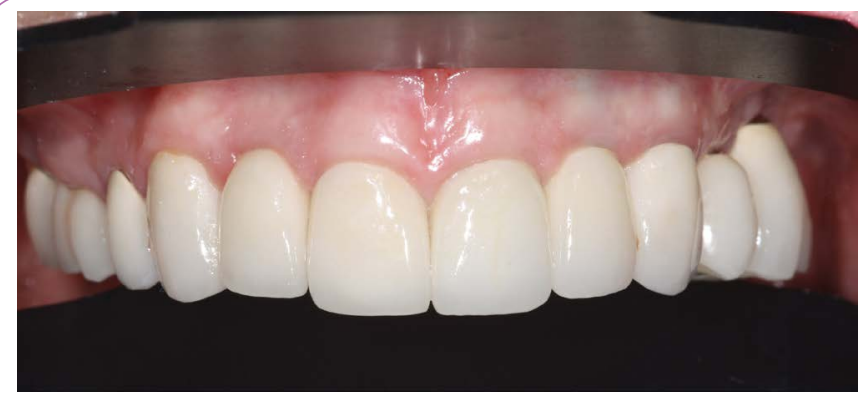

Figure 18 Facial view showing stable esthetic results at 24 months follow-up.

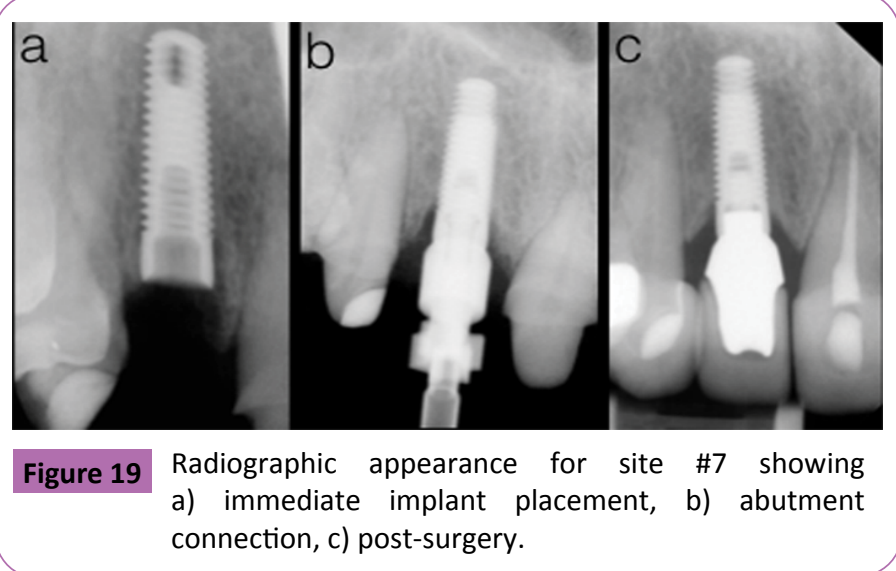

significantly greater around implants compared to natural teeth [27]. Considering the longer soft tissue components around dental implants, special care in soft tissue manipulation is necessary to avoid recession around dental implants compared to natural teeth. Since the soft tissue component is dependent on the underlying osseous crest present, bone sounding under local anesthesia was performed with a periodontal probe before flap reflection, to determine the level of the osseous crest and the need of osseous reduction. Then, esthetic crown lengthening was performed using gingivectomy only around dental implants compared to gingivectomy combined with osseous reduction around natural teeth.

Periodontal biotype is another important factor that must be considered during ECL as it impacts the healing and final gingival margin position. Claffey and Shanley described the biotype as thin with gingival thickness of $1.5 \mathrm{~mm}$ or less and thick with $2.0 \mathrm{~mm}$ or more [28]. Thin periodontal biotype patients are more likely to experience gingival recession compared to more tissue rebound in areas of thick biotype [29]. Further, increased distance of 3 $\mathrm{mm}$ or more between the bone crest and the CEJ is associated with recession [30]. The patient periodontal biotype in the current case report was "thick" and chances of recession were less likely. Soft tissue removal alone around the dental implants was adequate to attain gingival symmetry without compromising implant osseointegrated. In esthetically demanding areas, longer times for healing are desired to avoid gingival margin position changes. Different healing periods for soft tissues ranging from 6 weeks to 6 months have been reported with longer time required for thin biotype [31]. In areas of thick biotype around natural teeth, Pontoriero et al. recommended up to 1 year healing period before placement of final restorations due to tendency for coronal tissue migration [29]. Tomasi et al. investigated the morphogenesis of the peri-implant mucosa during the first 12 weeks of healing [29]. They observed that a soft tissue barrier adjacent to titanium implants developed completely within 8 weeks, which is in agreement with observations made in dogs [32]. The soft tissue barrier dimensions are stable around implants when observed over 12 [33] and 15 months [34,35] period. Given the aforementioned healing times for thin or thick biotypes, the impressions for the final restorations in this report were made after 8 weeks of healing and the final restorations were delivered 8 months post-surgery. The later allowed for complete tissue healing establishing stable gingival margin positions for esthetic results [29]. The soft tissue results remained stable at 12 and 24 months follow-ups.

To objectively evaluate the periodontal and restorative results of dental implants in the esthetic zone, Belser et al. described an assessment system [22]. The system records Pink Esthetic Scores (PES) to evaluate the periodontal tissues surrounding the implant and White Esthetic Scores (WES) to evaluate the restorative treatment. The variables assessed with PES are the mesial and distal papilla, level and curvature of the facial mucosa, and root convexity/color and texture of the soft tissue. Scores ranging from 0 to 2 is assigned to these parameters based on the complete presence, incomplete presence or absence of the papilla, curvature of the facial soft tissue line compared to control natural teeth, level of the peri-implant mucosa compared to the contralateral teeth, presence/partial presence or absence of a convex profile and the color and texture of the related mucosal surface. Symmetrical gingival margins with esthetically pleasing clinical crown width to length ratios were achieved for the dental implants and natural teeth. The WES and PES scores calculated at the 24 months follow up showed improved values compared to the pre-operative scores and the results were stable at 12 and 24 months follow-ups.

\section{Disclosure}

The authors declare no conflicts of interest. No author received any monetary compensation for this manuscript. 


\section{References}

1 Terry DA, McGuire M (2002) The perio-aesthetic-restorative approach for anterior reconstruction Part I: Evaluation and periodontal surgery. Pract Proced Aesthet Dent 14: 283-291.

2 Shaw WC, Rees G, Dawe M, Charles CR (1985) The influence of dentofacial appearance on the social attractiveness of young adults. Am J Orthod 87: 21-26.

3 Van der Geld P, Oosterveld P, Van Heck G, Kuijpers-Jagtman AM (2007) Smile attractiveness. Selfperception and influence on personality. Angle Orthod 77: 759-765.

4 Malkinson S, Waldrop TC, Gunsolley JC, Lanning SK, Sabatini R (2013) The effect of esthetic crown lengthening on perceptions of a patient's attractiveness, friendliness, trustworthiness, intelligence, and self-confidence. J Periodontol 84: 1126-1133.

5 Rosenberg ES, Garber DA, Evian Cl (1980) Tooth lengthening procedures. Compend Contin Educ Gen Dent 1: 161-172.

6 Levine RA, McGuire M (1997) The diagnosis and treatment of the gummy smile. Compend Contin Educ Dent 18: 757-762.

7 Coslet JG, Vanarsdall R, Weisgold A (1977) Diagnosis and classification of delayed passive eruption of the dentogingival junction in the adult. Alpha Omegan 70: 24-28.

8 Garber DA, Salama MA (1996) The aesthetic smile: diagnosis and treatment. Periodontol 2000 11: 18-28.

9 Lee EA (2004) Aesthetic crown lengthening: classification, biologic rationale, and treatment planning considerations. Pract Proced Aesthet Dent 16: 769-778.

10 Reeves WG (1991) Restorative margin placement and periodontal health. J Prosthet Dent 66: 733-736.

11 Nugala B, Kumar BS, Sahitya S, Krishna PM (2012) Biologic width and its importance in periodontal and restorative dentistry. J Conserv Dent 15: 12-17.

12 Planciunas L, Puriene A, Mackeviciene G (2006) Surgical lengthening of the clinical tooth crown. Stomatologija 8: 88-95.

13 AAID (2013) Dental Implants- Facts and Figures. American Academy of Implant Dentistry, Chicago, USA.

14 Chen ST, Buser D (2009) Clinical and esthetic outcomes of implants placed in postextraction sites. Int J Oral Maxillofac Implants 24: 186-217.

15 Bashutski JD, Wang HL, Rudek I, Moreno I, Koticha T, et al. (2013) Effect of flapless surgery on single-tooth implants in the esthetic zone: a randomized clinical trial. J Periodontol 84: 1747-1754.

16 Misje K, Bjornland T, Saxegaard E, Jensen JL (2013) Treatment outcome of dental implants in the esthetic zone: a 12- to 15-year retrospective study. Int J Prosthodont 26: 365-369.

17 Jacobson N, Starr C (2009) Flapless implant placement with crown lengthening procedure to correct crown height: a case report. Implant Dent 18: 387-392.

18 Carnevale G, Sterrantino SF, Di Febo G (1983) Soft and hard tissue wound healing following tooth preparation to the alveolar crest. Int J Periodontics Restorative Dent 3: 36-53.
19 Tarnow DP, Magner AW, Fletcher P (1992) The effect of the distance from the contact point to the crest of bone on the presence or absence of the interproximal dental papilla. J Periodontol 63: 995-996.

20 Salama H, Salama MA, Garber D, Adar P (1998) The interproximal height of bone: a guidepost to predictable aesthetic strategies and soft tissue contours in anterior tooth replacement. Pract Periodontics Aesthet Dent 10: 1131-1141.

21 Chu SJ, Tarnow DP, Tan JH, Stappert CF (2009) Papilla proportions in the maxillary anterior dentition. Int J Periodontics Restorative Dent 29: 385-393.

22 Belser UC, Grütter L, Vailati F, Bornstein MM, Weber H, et al. (2009) Outcome evaluation of early placed maxillary anterior singletooth implants using objective esthetic criteria: a crosssectional, retrospective study in 45 patients with a 2-to 4-year follow-up using pink and white esthetic scores. J Periodontol 80: 140-151.

23 Sterrett JD, Oliver T, Robinson F, Fortson W, Knaak B, et al. (1999) Width/length ratios of normal clinical crowns of the maxillary anterior dentition in man. J Clin Periodontol 26: 153.

24 Chu SJ (2007) Range and mean distribution frequency of individual tooth width of the maxillary anterior dentition. Practical Procedures and Aesthetic Dentistry 19: 209.

25 Perez JR, Smukler H, Nunn ME (2008) Clinical dimensions of the supraosseous gingivae in healthy periodontium. J Periodontol 79 : 2267-2272.

26 Gargiulo AW, Wentz FM, Orban B (1961) Dimensions and relations of the dentogingival junction in humans. J Periodontol 32: 261-267.

27 Berglundh T, Lindhe J, Ericsson I, Marinello C, Liljenberg B, et al. (1991) The soft tissue barrier at implants and teeth. Clin Oral Implants Res 2: 81-90.

28 Claffey N, Shanley D (1986) Relationship of gingival thickness and bleeding to loss of probing attachment in shallow sites following nonsurgical periodontal therapy. J Clin Periodontol 13: 654-657.

29 Pontoriero R, Carnevale G (2001) Surgical crown lengthening: a 12-month clinical wound healing study. J Periodontol 72: 841-848.

30 KOIS JC (1994) Altering gingival levels: the restorative connection part I: biologic variables. Journal of Esthetic and Restorative Dentistry 6: 3-7.

31 Brägger U, Lauchenauer D, Lang N (1992) Surgical lengthening of the clinical crown. J Clin Periodontol 19: 58-63.

32 Tomasi C, Tessarolo F, Caola I, Wennström J, Nollo G, et al. (2014) Morphogenesis of peri- implant mucosa revisited: an experimental study in humans. Clin Oral Implants Res 25: 997-1003.

33 Berglundh T, Abrahamsson I, Welander M, Lang NP, Lindhe J (2007) Morphogenesis of the periimplant mucosa: an experimental study in dogs. Clin Oral Implants Res 18: 1-8.

34 Assenza B, Scarano A, Petrone G (2003) Crestal bone remodeling in loaded and unloaded implants and the microgap: a histologic study. Implant Dent 12: 235-241.

35 Hermann JS, Buser D, Schenk RK, Higginbottom FL, Cochran DL (2000) Biologic width around titanium implants A physiologically formed and stable dimension over time. Clin Oral Implants Res 11: 1-11. 